\title{
Association of manganese superoxide dismutase gene polymorphism (Ala-9Val) and breast cancer in males and females
}

\author{
Associação do polimorfismo do gene da superóxido dismutase dependente de manganês (Ala-9Val) \\ em homens e mulheres com câncer de mama
}

Claudia Giuliano Bica'; Ivana Beatrice Mânica da Cruz $^{2}$; Leonardo Leiria de Moura da Silva ${ }^{3}$; Nadima Vieira Toscani ${ }^{3}$; Cláudio Galleano Zettler ${ }^{4}$; Márcia Silveira Graudenz ${ }^{5}$

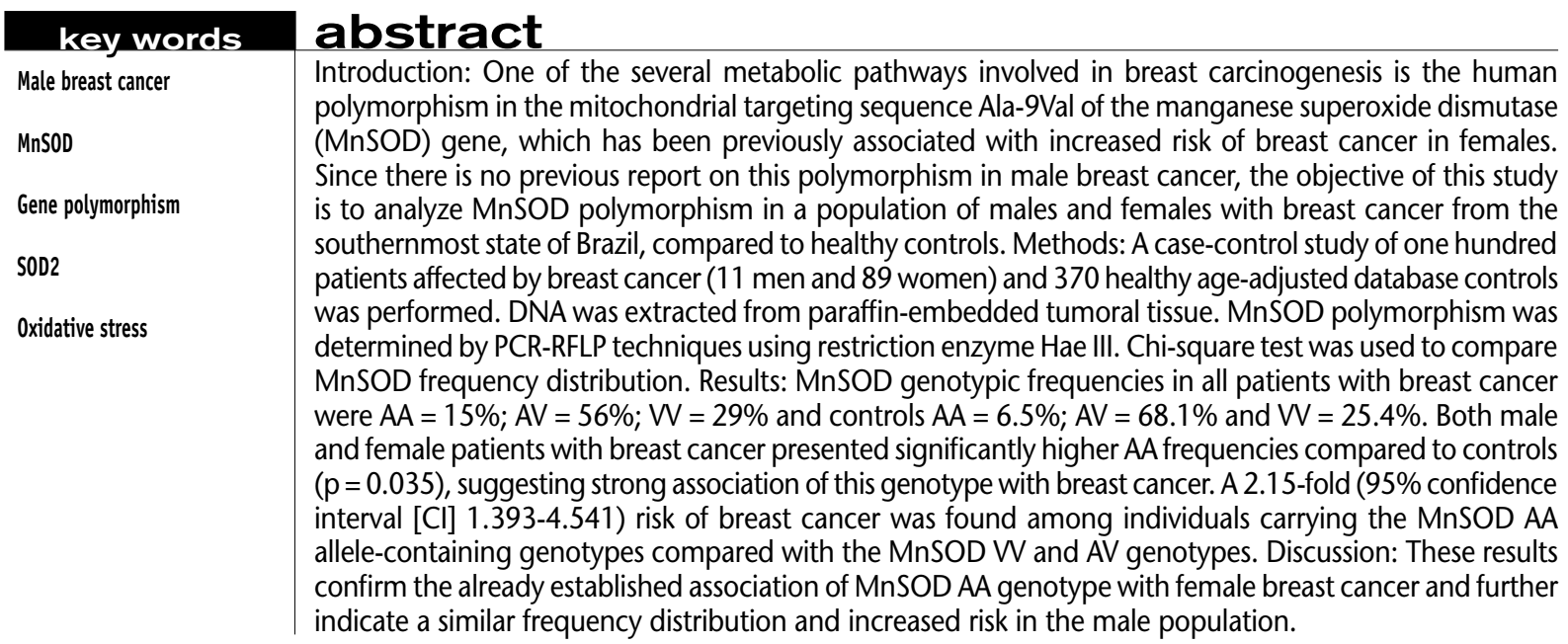

resumo

Introdução: Uma das diversas rotas metabólicas envolvidas no processo de carcinogênese da mama é o polimorfismo Ala-9Val do gene da superóxido dismutase dependente de manganês, cuja associação com o aumento do risco de câncer de mama em mulheres já é bem estabelecida na literatura. Contudo, não existem estudos envolvendo esse polimorfismo no carcinoma de mama em homens, principalmente devido à baixa prevalência dessa neoplasia. O objetivo deste estudo é analisar o polimorfismo da MnSOD em uma população de homens e mulheres com câncer de mama no sul do Brasil, comparando tais achados com controles saudáveis. Métodos: Foi realizado um estudo de caso-controle em cem pacientes com câncer de mama (11 homens e 89 mulheres) e 370 controles saudáveis. O DNA foi extraído do tecido tumoral emblocado em parafina. O polimorfismo da MnSOD foi determinado por técnicas de PCR-RFLP usando a enzima de restrição Hae III. O teste do qui quadrado foi usado para comparar a distribuição das freqüências dos polimorfismos. Resultados: As freqüências genotípicas dos pacientes com câncer de mama foram $A A=15 \% ; A V=56 \% ; V V=29 \%$ e dos controles $A A=$ $6,5 \% ; A V=68,1 \%$ e $V V=25,4 \%$. Os pacientes com câncer de mama, tanto as mulheres como os homens, apresentaram freqüencias significativamente mais elevadas do genótipo $A A$ quando comparadas aos controles $(p=0,035)$, sugerindo associação forte desse genótipo com o câncer de mama. O intervalo de confiança foi de 1,393-4,541 (95\%) e o risco encontrado foi de 2,15 para indivíduos portadores do genótipo AA, quando comparados com os controles que tinham os genótipos VV e AV da MnSOD. Discussão: Esses resultados confirmam a associação já estabelecida do genótipo da MnSOD AA com câncer de mama em mulheres e indicam distribuição de freqüência similar e risco aumentado na população masculina. unitermos

Câncer de mama em homens

MnSOD

Polimorfismo gênico

SOD2

Estresse oxidativo

\footnotetext{
1. Doutoranda do Programa de Pós-graduação em Patologia da Fundação Faculdade Federal de Ciências Médicas de Porto Alegre (FFFCMPA); professora assistente do Departamento de Ciências Fisiológicas da FFFCMPA.

2. Professora do Departamento de Morfologia; Centro de Ciências da Saúde da Universidade Federal de Santa Maria (UFSM).

3. Acadêmicos de Medicina da FFFCMPA.

4. Professor do Programa de Pós-graduação em Patologia da FFFCMPA.

5. Professora associada do Departamento de Patologia da FFFCMPA; coordenadora do Programa de Pós-Graduação em Patologia da FFFCMPA.

Trabalho desenvolvido no Programa de Pós-graduação em Patologia da FFFCMPA.
} 


\section{Introduction}

Breast cancer is one of the most common neoplastic diseases in Brazil, with 48,930 new cases expected each year. The southern states of the country (especially Rio Grande do Sul) present the higher occurrence of this disease, accounting 2,800 new diagnosed cases and 980 registered obits in $2005^{(18)}$. On the other hand, breast cancer in men is a rare disease, accounting for less than $1 \%$ of all breast cancer cases and $0.1 \%$ of cancer mortality in men ${ }^{(11)}$. To our knowledge, there are no epidemiological studies about male breast cancer (MBC) in Brazil. Studies are limited to single case reports or small case series, describing only clinical or pathological findings on each patient. The physiopathology of $M B C$ is not yet well known, what justifies the study of this disease and its risk factors in a large number of patients.

Risk factors associated with breast cancer, such as age, obesity, family history and reproductive patterns, had been well-established in literature. Also, a significant environmental effect was revealed by the major difference in breast cancer incidence among countries. The role of endogenous and exogenous estrogens to breast cancer risk, and the discovery and quantification of risk associated with several gene mutations are growing fields of investigation ${ }^{(10)}$. However, most studies only investigate the etiology of female breast cancer while few papers describe this tumor in the male gender. Due to such rarity, most of our knowledge on the etiology of MBC has been extrapolated from single case reports or small series of patients. These studies reveal that family history of breast cancer is associated with increased risk of male breast cancer. The association between estrogen levels and breast cancer in men is deduced from the fact that obesity has fairly consistently been associated with increased risk and implicated in the etiology of $\mathrm{MBC}$ due to higher circulating estrogen levels ${ }^{(16,35)}$.

In women, inherited breast cancer linked to germ line mutations in genes, such as BRCA1 and BRCA2, are responsible for $30 \%$ to $86 \%$ of all cases. In contrast, estimates have ranged from $4 \%$ to $40 \%$ for the proportion in men. Germ line mutations in the AR gene, which could activate estrogen-regulated genes, have been suggested to predispose to MBC. Another gene hypothesized to be associated with male breast carcinoma is CYP17, which codes an enzyme involved in the synthesis of estrogens and androgens, leading to increased steroid hormone production. Cowden syndrome is a cancer susceptibility syndrome associated with germ line mutations in the PTEN tumor-suppressor gene, which increases the risk of breast carcinoma.
Two cases of MBC have been reported in patients with classic Cowden syndrome phenotypes, who also had germ line PTEN mutations. Also, Klinefelter syndrome has been consistently associated with breast cancer in men. Men with Klinefelter syndrome tend to have lower levels of androsterone and normal to somewhat low levels of estrogens, resulting in a high estrogen/androgen ratio which can explain the predisposition to breast cancer ${ }^{(35)}$. The association between estrogen levels and breast cancer in men is of special interest because estrogen-related risk factors have been strongly implicated in the etiology of female breast cancer and could influence oxidative stress metabolism. Disorders related to hormonal imbalances, such as obesity, testicular disorders (e.g. cryptorchidism, mumps orchitis, and orchiectomy), radiation exposure, cancer, prostate cancer treatment, gynecomastia, occupational exposures (e.g. electromagnetic fields, polycyclic aromatic hydrocarbons, and high temperatures), dietary factors (e.g. meat intake and fruit and vegetable consumption), alcohol intake and genetic influences are related as main risk factors ${ }^{(35)}$.

Besides, induction of high levels of reactive oxygen species (ROS) produce a state of oxidative stress (OS) in cells, which may damage cellular DNA, proteins, and lipids resulting in cell-cycle arrest, cellular senescence, and cell death ${ }^{(15)}$. Chronic OS has been implicated in neoplastic transformation ${ }^{(29)}$ and promotion of tumorigenesis ${ }^{(2)}$, including steroid-influenced tumors, such as prostate and breast cancer ${ }^{(24,25)}$.

Within mitochondria, manganese superoxide dismutase (MnSOD) provides a major defense against oxidative damage by reactive oxygen species. A diallelic polymorphism (Ala$9 \mathrm{Val}$ ) in the mitochondrial targeting sequence (MTS) of human MnSOD has been previously reported. Calculation of a helix-forming potential predicted the typical amphiphilic helical structure in -9Ala allele and its disruption in -9Val allele. This mutation may reflect functional polymorphism of mitochondrial transport of human MnSOD. Ala-9Val is implicated in decreased efficiency of MnSOD transport into target mitochondria in $\mathrm{V}$ allele carriers ${ }^{(30)}$. A study performed by Sutton et al. ${ }^{(30)}$ suggested that the Ala-MnSOD precursor generated $30 \%-40 \%$ more of the active matricial processed MnSOD homotetramer than the Val-MnSOD precursor. These results showed that the Ala-MnSOD/mitochondrial targeting sequence (MTS) allows efficient MnSOD import into the mitochondrial matrix, while the Val-variant causes partial arrest of the precursor within the inner membrane and decreased formation of the active MnSOD tetramer in the mitochondrial matrix. 
The major source of ROS generation is the mitochondria respiratory chain. The superoxide dismutase (SOD) enzymatically converts the radical superoxide into hydrogen peroxide. In humans, there are three forms of SOD: cytosolic and extracellular Cu-Zn SOD (SOD1 and SOD3) and mitochondrial MnSOD (SOD2). Several lines of evidence suggest that SOD2 is a tumor-suppression gene. Human polymorphism (Ala-9Val) in the mitochondrial targeting sequence of this radical-scavenging enzyme encodes for either alanine (Ala) or valine (Val) in the MTS of human SOD2 and has been previously associated with diseases. Although the AA genotype presents highest MnSOD activity, several studies have described association between this genotype and cancer, including breast ${ }^{(17,20,32)}$, prostate ${ }^{(32,36)}$, lung ${ }^{(33)}$ and colorectal carcinoma ${ }^{(28)}$. However, other studies did not find the same results ${ }^{(3,12)}$, probably because of gene-gene, gene-environmental and physiological interactions associated with MnSOD polymorphism and cancer.

It is not yet known whether physiological interactions, such as steroid metabolism, could influence the interaction between MnSOD polymorphism and breast cancer risk. Since the major risk factors for female breast cancer are associated with prolonged exposure to increased levels of estrogen, enhanced cell proliferation induced either by endogenous or exogenous estrogens would increase the number of cell divisions and thereby the possibility for mutation. Recently, Mitrunen and Hirvonen ${ }^{(19)}$ studied the potential role of polymorphic genes encoding for enzymes involved in estrogen biosynthesis and conversion of estrogen metabolites and their by-products as MnSOD in modulating individual susceptibility to breast cancer. The authors suggested that, although some of those genes showed low penetrance, they appeared as good risk factor candidates for sporadic breast cancer. However, those results are still obscure and need additional evidence, including populational analysis using biological material from different tissues.

Although several studies have demonstrated the association between female breast cancer and MnSOD polymorphism, so far no report has been published about male breast cancer. The objective of this study was to investigate MnSOD polymorphism in males with breast cancer compared to healthy controls and to female breast cancer.

\section{Methodology}

\section{Study participants}

This study included 470 subjects distributed in four groups: male breast cancer $(M B C=11)$, female breast cancer $(F B C=89)$, female controls $(F C=217)$ and male controls $(M C=153)$.

Patients with breast cancer were consecutively recruited from January 2003 to November 2004 at breast cancer centers and pathology laboratories from three hospitals localized in Porto Alegre, Brazil (Hospital Santa Rita, Hospital Conceição and Hospital São Lucas). Patients diagnosed with invasive ductal or lobular breast carcinoma during the studied period met the inclusion criteria. There were no age or stage restrictions.

Control individuals were recruited from an existing database of 746 socially active healthy subjects, who took part in a community-based research named Programa Genesis de Pesquisa, that investigates genetic-environmental interactions on human ageing ${ }^{(6,23)}$. The investigation was structured considering the checklist for reporting and appraising of gene-disease associations proposed by Little et al. ${ }^{(14)}$.

Healthy controls were selected according to clinical general health status and were frequency matched for age to the expected age distribution of the cases. The control exclusion criteria were: infections, acute or chronic inflammation, autoimmune diseases, heart disease, undernourishment, anemia, leucopenia, clinical depression, neurodegenerative disease, and other previous neoplasia. The exclusion of subjects affected by those diseases was based on the reported association between $\mathrm{V}$ allele and coronary disease ${ }^{(13)}$.

The study protocol was approved by the institutional review boards of all relevant institutions and informed consent was obtained from all individuals whose information was prospectively collected.

\section{MnSOD genotyping}

Genomic DNA was isolated from peripheral blood leukocytes (controls and cases) and from tissue samples (cases) using a DNA Mini Kit Purification (Mo Bio). The methodology used here to detect Ala-9Val polymorphism is described in details in Taufer et al. ${ }^{(32)}$. PCR amplifications were performed at a total volume of $50 \mu \mathrm{l}$ containing 10x buffer $5 \mu \mathrm{l}, 25 \mathrm{mM} \mathrm{MgCl} 21 \mu \mathrm{l}, 10 \mathrm{mM}$ dNTP 1.25 $\mu \mathrm{l}$, Taq Polymerase $0.5 \mu \mathrm{l}$ (Gibco Inc, Co.), $40 \mathrm{pmol}$ each primer $1 \mu \mathrm{l}$, Genomic DNA $3 \mu \mathrm{l}(0.25 \mu \mathrm{g})$, ddH2O $34.5 \mu \mathrm{l}$. The amplification primers (Gibco Inc, Co.) for a $110 \mathrm{bp}$ fragment of the human MnSOD gene were 5'ACCAGCAGGCAGCTGGCGCCGG-3', (sense strand) and 5'-GCGTTGATGTGAGGTTCCAG-3' (antisense strand) with 
thermocycler parameters comprised of an initial cycle of $95^{\circ}$ for five minutes followed by 35 cycles at $95^{\circ}$ for one minute, $61^{\circ}$ for one minute. The final cycle was followed by an extension period of two minutes at $72^{\circ}$. PCR product $(10 \mu \mathrm{l})$ was digested with Hae III $\left(15 \mathrm{U} ; 37^{\circ}, 6 \mathrm{~h}\right.$, Gibco. Inc, Co.). Digested products ( 23 and $85 \mathrm{pb}$ ) were visualized on a $4 \%$ agarose gel (Amersham Biosciences Inc, Co.) stained with ethidium bromide. A mutation was introduced by a primer mismatch to create a restriction cut site for Hae III in the -9 codon, though the following genotypes were observed: -9Ala/Ala (23 and 85bp); -9Ala/Val (23, 85 and $110 \mathrm{bp}) ;$ and $-9 \mathrm{Val} / \mathrm{Val}$ (110 bp).

\section{Statistic analysis}

Allele frequencies were estimated by the gene-counting method. Chi-square $(\chi 2)$ analysis was used to estimate the Hardy-Weinberg equilibrium. The allelic and genotype frequencies were compared among groups using the chisquare statistical test or the exact Fisher test. All significant levels were two-tailed. Confidence intervals $(\mathrm{Cl})$ of $95 \%$ were determined for genotype comparisons. The alpha value considered was $p=0.05$. A computer statistics package (SPSS 11.0, Chicago, USA) was used for statistical analyses in this study.

\section{Results}

The study included 470 subjects: one hundred cases who were diagnosed with breast cancer aged between 44 and 89 years, and 370 control individuals aged between 47 and 86 years. Male control mean age was $63.16 \pm 7.05$; female control mean age was $64.24 \pm 7.6$; male breast cancer mean age was $64.25 \pm 11.63$ and female breast cancer mean age was $63.74 \pm 8.52$. The mean ages among groups were statistically similar $(p=0.136)$.

The genotype distribution for MnSOD polymorphism in all subjects analyzed in this series was: $\mathrm{AA}=8.3 \%(n=$ $39) ; \mathrm{V}=26.2 \%(n=123) ; \mathrm{AV}=65.5 \%(n=308)$. Allelic frequencies were $A=0.424$ and $V=0.586$, respectively. The genetic frequencies were in Hardy-Weinberg equilibrium.

We analyzed MnSOD polymorphism frequencies comparing breast and control groups. When we compared males (case and controls) and females (case and controls) separately, considering the three genotypes, we did not find statistic association.

$A A$ and $A V+V V$ genotype frequency comparison among all groups are presented in Table 1. We grouped the sample in two general groups (case and controls) using the Pearson chi-square analysis. The results are described in Table 2. Statistical differences were observed when case and control groups were compared for AA genotype (Pearson chi-square $=7.449 ; p=0.006$ ).

\begin{tabular}{lcccc|} 
& \multicolumn{3}{c}{$\begin{array}{l}\text { Comparison of genotype frequency } \\
\text { among breast cancer and control }\end{array}$} \\
Table & $\mathbf{1}$ & \multicolumn{2}{c}{ groups } \\
Geno- & \multicolumn{2}{c}{ Controls } & \multicolumn{2}{c}{ Cases } \\
types & \multicolumn{2}{c}{$n(\%)$} & \multicolumn{2}{c}{$n(\%)$} \\
& Male & Female & Male & Female \\
AA & $6(3.9)$ & $18(8.3)$ & $1(9.1)$ & $14(15.7)$ \\
AV + & $147(96.1)$ & $199(91.7)$ & $10(90.9)$ & $75(84.3)$ \\
W & & & & \\
\hline
\end{tabular}

Pearson Chi-square $=10.21, p=0.016$

\section{Comparison of MnSOD} polymorphism frequency among

Table 2 cancer and control groups

\begin{tabular}{lccc}
\hline Genotypes & Case $n(\%)$ & Control $n(\%)$ & OR (95\% CI) \\
AA & $15(15)$ & $24(6.5)$ & 2.544 \\
& & & $(1.279-5.059)$ \\
VV + AV & $85(85)$ & $346(93.5)$ & \\
VV & $29(29)$ & $94(25.4)$ & 1.199 \\
& & & $(0.734-1.960)$ \\
AA + AV & $71(71)$ & $276(74.6)$ & \\
\hline
\end{tabular}

$O R=$ odds ratio; $C l=$ confidence interval.

\section{Discussion}

The association observed from our results could be explained by some biochemical evidence reported in literature that suggests association between breast cancer and oxidative stress metabolism ${ }^{(21)}$. The degree of ROS in a cell is dependent on the balance between ROS anabolism and catabolism. There are a number of reports that establish a link between estrogen-induced breast cancer and oxidative stress ${ }^{(4,34,37)}$. In fact, a variety of estrogens are capable of acting as complete carcinogens through a mechanism that involves oxidative stress in the kidney, liver and breast tissues of various rodent model ${ }^{(4,9)}$. Furthermore, oxidative DNA damage is reportedly increased in breast cancer tissues relative to normal breast, with a strong correlation to estrogen receptor (ER) status ${ }^{(22)}$. 
Some ROS may be generated from estrogen metabolism through catechol redox cycling. Mitrunen et al.(20), who studied female Finnish Caucasian population and reported that the Ala allele was associated with breast cancer risk, found that postmenopausal women who had used estrogen replacement therapy and carried either Ala/Ala or Val/Ala genotype had a 2.5 -fold higher risk for breast cancer. Women who had used oral contraceptives and carried Ala/Ala or Val/Ala genotype presented a threefold higher risk for breast cancer. More recently, Egan et al.(7) conducted a population-based case-control study among 476 cases and 502 controls in an American population. Overall, relative risks were not significantly elevated in women with one (odds ratio [OR] 1.27, $95 \mathrm{Cl} 0.91-1.77$ ) or two (OR 1.18, 95\% Cl 0.81-1.73) Ala alleles, as compared with $\mathrm{Val} / \mathrm{Val}$ genotype. Risk, however, was increased among premenopausal women carrying the Val/Ala genotype (OR 1.88 ), but not among women carrying the Ala/Ala genotype (OR 0.94). Women carrying Ala/Ala or Val/Ala genotype who had used oral contraceptives or had higher body mass index (BMI) also showed increased risk for breast cancer.

First of all, we observed significant association between MnSOD Ala/Ala genotype and breast cancer when male and female cases are grouped together. To our knowledge, this is the first report in literature to suggest a possible association of this polymorphism to male breast cancer. However, these results should be carefully interpreted, mainly because of two points: the small number of males with breast cancer and the single case of $\mathrm{MBC}$ of $\mathrm{AA}$ genotype in our sample. Since $M B C$ is a rare and uncommon disease ${ }^{(35)}$, with many pathways involved in its carcinogenic process, any conclusions regarding this tumor must be taken with special caution. Our considerable sample of 11 cases, enrolled in a time period of 13 years (1993 to 2005), enforces the assumption that MnSOD polymorphism may be involved in this tumor. Taking these results in perspective, our study highlights for the first time that MnSOD polymorphism may be involved, at some degree, in male breast carcinogenesis, as well as in its female counterpart.

Despite the small sample number, when we performed the statistical analysis we found 2.544 times risk of the AA genotype to present in breast cancer. This risk was higher than the one described by Mitrunen et al. ${ }^{(20)}$, that studied 483 breast cancer cases and 482 controls, all of Finnish Caucasian origin, and described 1.5-fold (95\% Cl 1.1-2) breast cancer risk associated with AA genotype. However, the risk described here was near to the one reported by Cai et al.(3), who studied 1,125 breast cancer cases and
1,197 age-frequency-matched control individuals. The authors found that Ala/Ala genotype was breast cancerassociated among premenopausal women with higher body mass index (OR $2.5,95 \% \mathrm{Cl} 0.9-7$ ) and more years of menstruation (OR 2.6, 95\% Cl 0.8-8). However, it is important to comment that the study of Cai et al. ${ }^{(3)}$ was performed in Asian population, which has very low Ala/Ala frequency. On the contrary, several studies, as performed by Milikan et al. (17), Tamimi et al. ${ }^{(31)}$, Egan et al. ${ }^{(7)}$, did not find independent association between MnSOD polymorphism and breast cancer. These apparently contradictory results could be analyzed considering two points: biological plausibility and the gene-environmental and gene/gene interactions influence.

On the other hand, we need to consider the possible gene-environmental and gene-gene interactions occurrence that could influence the results described here. Several studies have postulated that Ala-9Val MnSOD polymorphism and cancer association are influenced by variables, such as food (vegetables and meat), high alcohol consumption, smoking habit, pesticide exposition $(1,8,26,27)$. Some studies reported possible gene-gene association, such as performed by Cox et al.(5), that described interaction MnSOD and glutathione peroxidase (GPX-1) gene polymorphisms associated with increased risk of breast cancer. These results postulate that the occurrence of substantial interaction with pro- or anti-oxidant properties exposures (from environmental or genetic origin) could interfere in $\mathrm{MnSOD}$ polymorphism and breast cancer association. Our study did not analyze the influence of those possible environmental and genetic variables, which could particularly influence our results. But since it is well-established that breast cancer is a multifactorial disease, the study of each one of those factors, when taken in perspective, may shed some light on breast cancer physiopathology. Therefore, complementary studies analyzing environmental lifestyle variables, such as food, smoking and alcohol habits, stress exposition and others, could be useful to understand the possible association between the polymorphism analyzed here and breast cancer.

The results shown in Table 1 demonstrate small frequencies of the AA genotype in the male control group $(3.9 \%)$ in contrast to the male breast cancer group $(9.1 \%)$, which was almost three times higher. Despite not having statistical difference, those frequencies could indicate a possible association of that polymorphism with male breast cancer, regarding the small number of patients. Further studies that analyze not only that polymorphism, but also 
other risk factors, in a larger number of males with breast cancer, may help understanding this uncommon disease.

In conclusion, our preliminary data presented a positive association between the homozygous MnSOD Ala/Ala genotype and significantly elevated risk of male and female breast cancer. These findings suggest that individual susceptibility of breast cancer may be modulated by MnSOD polymorphism, and the combination of genetic factors involved in oxidative stress response with environmental and/or endogenous carcinogens may play a role in breast carcinogenesis.

However, the small numbers of individuals with male breast cancer may result in unstable OR estimates and limited statistical power for stratified analyses, limiting the study. Further studies with larger sample sizes to offer sufficient statistical power also for the subgroup analyses are therefore evidently needed before any strict conclusions can be drawn on this issue.

\section{Acknowledgments}

The authors thank the team of Projeto Genesis Gravataí for helping in data collection and molecular biology analysis; and CNPq, CAPES and FAPERGS for grants and fellowships.

\section{Referências}

I. AMBROSONE, C.B. et al. Manganese superoxide dismutase (MnSOD) genetic polymorphisms, dietary antioxidants, and risk of breast cancer. Cancer Res, v. 59, n. 3, p. 602-6, 1999.

2. ARBISER, J.L. et al. Reactive oxygen generated by NoxI triggers the angiogenic switch. Proc Natl Acad Sci USA, v. 99, n. 2, p. 7|5-20, 2002.

3. CAl, Q. et al. Genetic polymorphism in the manganese superoxide dismutase gene, antioxidant intake, and breast cancer risk: results from the Shanghai Breast Cancer Study. Breast Cancer Res, v. 6, n. 6, p. R647-55, 2004.

4. CAVALIERI, E. et al. Estrogens as endogenous genotoxic agents: DNA adducts and mutations. J Natl Cancer Inst Monogr, v. 27, p. 75-93, 2000.

5. COX, D.G.; TAMIMI, R.M.; HUNTER, D.J. Gene x gene interaction between MnSOD and GPX-I and breast cancer risk: a nested case-control study. BMC Cancer, v. 6 , p. 217-9, 2006.

6. Da CRUZ, I.B. et al. Angiotensin I-converting enzyme gene polymorphism in two ethnic groups living in Brazil's southern region: association with age.J Gerontol A Biol Sci Med Sci, v. 58, n. 9, p. M85I-6, 2003.

7. EGAN, K.M. et al. MnSOD polymorphism and breast cancer in a population-based case-control study. Cancer Lett, v. 199 , n. I, p. 27-33, 2003.

8. GAUDET, M.M. et al. MnSOD Val-9Ala genotype, pro- and anti-oxidant environmental modifiers, and breast cancer among women on Long Island, New York. Cancer Causes Control, v. 16, n. 10, p. 1225-34, 2005.

9. HAN, X.; LIEHR, J.G. 8-Hydroxylation of guanine bases in kidney and liver DNA of hamsters treated with estradiol: role of free radicals in estrogen-induced carcinogenesis. Cancer Res, v. 54, n. 21 , p. 55I5-7, 1994

I0. HANKINSON, S.E.; COLDITZ, G.A.; WILLET, W.C. Towards an integrated model for breast cancer etiology: the lifelong interplay of genes, lifestyle, and hormones. Breast Cancer Res, v. 6, n. 5, p. 213-8, 2004

I I. HILL, T.D. et al. Comparison of male and female breast cancer incidence trends, tumor characteristics, and survival. Ann Epidemiol, v. 15, n. 10, p. 773-80, 2005.

12. HUNG, R.J. et al. Genetic polymorphisms of MPO, COMT, MnSOD, NQOI, interactions with environmental exposures and bladder cancer risk. Carcinogenesis, v. 25, n. 6, p. 973-8, 2004.

13. LI, Y. et al. Dilated cardiomyopathy and neonatal lethality in mutant mice lacking manganese superoxide dismutase. Nat Genet, v. II, n. 4, p. 376-8I, 1995

I4. LITTLE, J. et al. Reporting, appraising and integrating data on genotype prevalence and gene-disease associations. Am J Epidemiol, v. I56, n. 4, p. 300- 10, 2002.

15. MARTINDALE, J.L.; HOLBROOK, N.J. Cellular response to oxidative stress: signaling for suicide and survival.J Cell Physiol, v. 192, n. I, p. I- 15, 2002.

16. MEIJER-VAN GELDER, M.E. et al. Clinical relevance of biologic factors in male breast cancer. Breast Cancer Res Treat, v. 68, n. 3, p. 249-60, 2001

17. MILLIKAN, R.C. et al. Manganese superoxide dismutase Ala-9Val polymorphism and risk of breast cancer in a populationbased case-control study of African Americans and whites. Breast Cancer Res, v. 6, n. 4, p. R264-74, 2004.

I8. MINISTÉRIO DA SAÚDE. Estimativa 2006. Incidência de câncer no Brasil. Rio de Janeiro: INCA, 2006.

19. MITRUNEN, K.; HIRVONEN, A. Molecular epidemiology of sporadic breast cancer. The role of polymorphic genes involved in oestrogen biosynthesis and metabolism. Mutat Res, v. 544, n. I, p. 9-41, 2003.

20. MITRUNEN, K. et al.Association between manganese superoxide 
dismutase (MnSOD) gene polymorphism and breast cancer risk. Carcinogenesis, v. 22, n. 5, p. 827-9, 200 I

2।. MOBLEY, J.A.; BRUEGGEMEIER, R.W. Estrogen receptormediated regulation of oxidative stress and DNA damage in breast cancer. Carcinogenesis, v. 25, n. I, p. 3-9, 2004

22. MUSARRAT, J.;AREZINA-WILSON, J.;WANI,A.A. Prognostic and aetiological relevance of 8-hydroxyguanosine in human breast carcinogenesis. Eur J Cancer, v. 32A, n. 7, p. I209-14, 1996.

23. PERES, A. et al. Immunophenotyping and T-cell proliferative capacity in a healthy aged population. Biogerontology, v. 4, n. 5, p. 289-96, 2003.

24. ROSS, R.K. et al. Androgen metabolism and prostate cancer: establishing a model of genetic susceptibility. Cancer Research, v. 58, n. 20, p. 4497-504, 1998.

25. SCHWARTZ, J.L.; ANTONIADES, D.Z:; ZHAO, S. Molecular and biochemical reprogramming of oncogenesis through the activity of prooxidants and antioxidants. Ann NY Acad Sci, v. 686, p. 262-78, 1993

26. SILVA, S.N. et al. Breast cancer risk and polymorphisms in genes involved in metabolism of estrogens (CYPI7, HSD I7betal, COMT and MnSOD): possible prospective role of MnSOD gene polymorphism Val/Ala and Ala/Ala in women that never breast fed. Oncol Rep, v. I6, n. 4, p. 78I-8, 2006.

27. SLANGER, T.E.; CHANG-CLAUDE, J.; WANG-GOHRKE, S. Manganese superoxide dismutase Ala-9Val polymorphism, environmental modifiers, and risk of breast cancer in a German population. Cancer Causes Control, v. 17, n. 8, p. 1025-31, 2006.

28. STOEHLMACHER, J. et al. The -9Ala/-9Val polymorphism in the mitochondrial targeting sequence of the manganese superoxide dismutase gene (MnSOD) is associated with age among Hispanics with colorectal carcinoma. Oncol Rep, v. 9, n. 2,p. 235-8, 2002.
29. SUH, Y.A. et al. Cell transformation by the superoxidegenerating oxidase MoxI. Nature, v. 40 I, p. 79-82, 1999 ,

30. SUTTON, A.; KHOURY, H.; PRIP-BUUS, C. The Alal6Val genetic dimorphism modulates the import of human manganese superoxide dismutase into rat liver mitochondria. Pharmacogenetics, v. I3, n. 3, p. 145-57, 2003.

31. TAMIMI, R.M. et al. Manganese superoxide dismutase polymorphism, plasma antioxidants, cigarette smoking, and risk of breast cancer. Cancer Epidemiol Biomarkers Prev, v. 13, n. 6, p. 989-96, 2004,

32. TAUFER, M. et al. Is the Vall 6Ala manganese superoxide dismutase polymorphism associated with the aging process? J Gerontol A Biol Sci Med Sci, v. 60, n. 4, p. 432-8, 2005.

33. WANG, L.I.; NEUBERG, D.; CHRISTIANI, D.C. Asbestos exposure, manganese superoxide dismutase (MnSOD) genotype, and lung cancer risk. J Occup Environ Med, v. 46, n. 6, p. 556-64, 2004.

34. WANI, G.; MILO, G.E.; D'AMBROSIO, S.M. Enhanced expression of the 8-oxo-7,8-dihydrodeoxyguanosine triphosphatase gene in human breast tumor cells. Cancer Lett, v. 125, n. I-2, p. 123-30, 1998.

35.WEISS, J.R.; MOYSICH, K.B.; SWEDE, H. Epidemiology of male breast cancer. Cancer Epidemiol Biomarkers Prev, v. I4, n. I, p. 20-6, 2005.

36. WOODSON, K. et al. Manganese superoxide dismutase (MnSOD) polymorphism, alpha-tocopherol supplementation and prostate cancer risk in the alpha-tocopherol, betacarotene cancer prevention study (Finland). Cancer Causes Control, v. I4, n. 6, p. 513-8, 2003.

37. YAGER, J.D.; LIEHR, J.G. Molecular mechanisms of estrogen carcinogenesis. Annu Rev Pharmacol Toxicol, v. 36, p. 20332, 1996.

\begin{tabular}{l|l} 
Mailing address \\
\hline & Claudia Ciuliano Bica \\
& Fundação Faculdade Federal de Ciências Médicas de Porto Alegre \\
& Rua Sarmento Leite, 245 - sala 304 \\
CEP 90.050-170 - Porto Alegre-RS & \\
Tel./Fax: +55 (51) 3303-9000 & e-mail: bicaclaudia@hotmail.com ou claudia@fffcmpa.edu.br
\end{tabular}

